\title{
How is the Learning Process and Assessment in E-Learning According to Japanese High School/ Vocational High School Teachers in Bali
}

\author{
Desak Made Sri Mardani ${ }^{1, *}$ I Wayan Sadyana ${ }^{1}$ \\ ${ }^{I}$ Japanese Language Education Study Program, Universitas Pendidikan Ganesha, Singaraja, Indonesia \\ "Corresponding author.Email: desak.mardani@undiksha.ac.id
}

\begin{abstract}
E-learning used during this pandemic is new for Japanese high school/vocational teachers in Bali, where previous faceto-face learning was done. This causes the teacher's lack of experience in implementing e-learning. The teacher's lack of experience certainly has an influence on the learning process, as well as the Assessment made by the teacher. For this reason, it is necessary to conduct research related to the learning process and Assessment in e-learning from the teacher's perspective. This study uses a descriptive quantitative approach. The questionnaire data of the research were analyzed using a t-test and analysis of variance (ANOVA). A purposive online survey was participated by 117 high school/vocational Japanese language teachers in Bali conducted from October to December 2020. There are no significant differences between male and female teachers, between teachers with bachelor and master levels, and between teachers with different teaching periods. This can also be seen in the teacher's perspective on the assessments carried out during e-learning, between female and male teachers, and between teachers at the bachelor and master levels. However, from the perspective of the Assessment between teachers who have different years of teaching experience, several significant differences were found. During the implementation of e-learning, teachers encountered problems in the learning process and Assessment, which stemmed from the lack of facilities, lack of student readiness, and lack of teaching experience in planning assessments that we're able to show students' abilities objectively.
\end{abstract}

Keywords: Purposive Online Survey, Learning Process, Assessment.

\section{INTRODUCTION}

Success in achieving learning objectives is closely related to the learning process, and Assessment carried out by the teacher. How the learning steps are carried out in the classroom greatly affects the skills possessed by students. Therefore planning a lesson is very important to do. Planning a lesson is certainly different if the class that is managed is not the same as usual. As at the present time, due to the COVID-19 pandemic, classes that are usually conducted face-to-face are conducted online. Classroom management in e-learning is certainly something new and a challenge for a teacher, especially for teachers who are not familiar with the use of electronic goods/technology in learning. Apart from these challenges, there are other challenges in learning foreign languages, such as Japanese.

In learning Japanese at the basic level, students are required to have communication skills using Japanese [1]. To achieve this, of course, the practice of communicating with friends is important. This requires the teacher's skills in planning e-learning so that students are able to practice with their friends so that they are able to communicate in Japanese.

In 2020, online learning at all levels of education is still managed independently by teachers with all their limitations and is still guided by the 2013 curriculum. Literacy, 4C (Communication, Collaboration, Critical thinking and Problem Solving, and Creativity and Innovation), and HOTS (Higher Order Thinking Skill). No exception in learning Japanese, the demands of the 2013 curriculum are also incarnated in the learning process. But what if the learning that is always done faceto-face then turns into e-learning? What is the teacher's perspective on learning Japanese online both in the learning process and in the Assessment?

The concept of e-learning provides convenience for anyone who is interested in learning, which has limited time, limited distance, workers who want to increase 
knowledge without having to leave their job. E-learning is a learning process that uses internet-based media, where educational technology is equated with various terms such as online learning, virtual classroom, and virtual learning [2]. According to Clark and Mayer [3], elearning is any instruction delivered on a computer that has characteristics, which include: a) content that is relevant to learning objectives, b) using instructional methods such as examples and practices to help to learn, c) using media elements such as sentences and pictures to distribute content and learning methods, d) building new insights and techniques related to learning objectives, and e) learning can be direct with the instructor (synchronous) or learning individually (asynchronous).

Effective e-learning should meet certain criteria as stated by [3], namely: a) the achievement of learning objectives, b) e-learning is easy on accessibility, c) has consistent and accurate messages, d) is easy to use, and e) relevant. E-learning utilizes learning resources that are accessed by computer to the internet to meet the needs of students who will learn. Thus facilities such as ICT and networks also play an important role in the e-learning process. What if the required facilities are not fully supported? As found by [4] how facilities are an obstacle in e-learning at one university in Indonesia. This of course, will be a problem that leads to the quality of learning and learning achievement.

As stated above, the use of e-learning in language learning has its own challenges for teachers. The use of e-learning in language learning has been widely carried out, such as in learning English. Learning English using e-learning appropriately can improve teacher performance and improve the quality of students' English [5]. Even the use of various learning media that can be obtained via the internet helps students in mastering the language because it is able to bring out the use of authentic language ([6],[7]). The use of ICT, which is part of e-learning, is very useful in foreign language learning because it is able to maximize communication between teachers and students, and even students try to expand their understanding of the use of ICT so that learning can run well [8]. Thus, the process of language learning through e-learning is still able to help students in mastering the language. Assessment is also a determining factor in improving a student's skill.

Assessment has the main principle, namely the backwash effect (Assessment must have a back impact). By providing the right Assessment, both teachers and students are able to see their weaknesses and strengths so that they are able to later make improvements in their learning process. This of course, will experience changes at this time, where teachers cannot carry out direct learning and assessments to students. The teacher cannot make observations on student activities in class. With the change in the learning system to e-learning, of course, teachers must think about ways of assessing that are able to show student performance objectively.

E-learning in principle, has a function to make it easier for teachers to convey messages/materials to students considering that face-to-face learning is not possible. However, this will be different if e-learning is a new thing for Japanese high school/vocational teachers in Bali. This raises a different perspective for teachers due to the emergence of obstacles in the learning and assessment process. Therefore, it is very important to know the problems experienced by the teacher and then make improvements in order to achieve the learning objectives. Through a questionnaire given to high school/vocational Japanese language teachers in Bali, it is known how the teacher's perspective on the learning process and Assessment during e-learning is carried out during 2020.

Like language learning, Japanese language learning is also directed at forming communicative abilities at certain levels. Theoretically, the process of learning Japanese at the primary group consists of the following stages: understanding (導入 (Introduction) Donyuu), remembering (基本練習 (Basic practice), and using (応 用練習 (Practicing Using) [1]. Therefore, in learning Japanese in the classroom, teaching steps are designed that are tailored to the language learning process. Thus, in one learning meeting, whatever strategy is used, it will undoubtedly go through a process of 'understanding' concepts (vocabulary, sentence patterns, and letters), 'remembering' these concepts, and 'using' these concepts. Even in the learning approach used in the 2013 curriculum, which prioritizes student-centeredness, these stages still exist.

The 2013 curriculum learning emphasizes the process, not the final result. Based on the 2013 curriculum, the learning process focuses on 21 st-century skills (in lesson plan) namely character education revitalization / KDP (religious, nationalist, independent, mutual cooperation and integrity), literacy, 4C (Communication, Collaboration, Critical thinking and Problem Solving, and Creativity and Innovation), as well as HOTS (Higher Order Thinking Skill) [9]. To be able to describe the learning process carried out by students, the Assessment carried out is more on process assessment.

Popham et al. [10] reveal that "assessment is concerned with collecting data on the dynamics, effectiveness, acceptability, and efficiency of a language program to facilitate decision making." An assessment can be done by taking a measurement. The Assessment used a tool that is classified into two, namely test and non-test. Non-test includes graded scales, questionnaires, interviews, and so on. While the test, according to [11], is "an information-gathering tool but when compared to other tools (nontest), the test is more official because it is 
full of limitations". There is an understanding of the test given by [12], which is "a tool to measure something abstract such as the ability to think, remember, and the ability to speak, write or other language skills, which then produces a score which is then interpreted in the evaluation stage." Thus, the test is one of the tools/methods used in a series of conducting an evaluation of learning. Through the implementation of the test, it will be known how much the learner understands the material provided, so that input will be obtained on the performance of the learning itself.

Assessment in the 2013 curriculum emphasizes reviews that are able to demonstrate the competence of students as a whole regarding aspects of knowledge (cognitive), skills (psychomotor), and effectiveness. Such competence can be raised if using an authentic assessment. Authentic Assessment was introduced by Grant Wiggint [13], which assesses students in applying their knowledge and skills as they experience in the real world. There are two principles in authentic Assessment, including Assessment using various measures, methods, and criteria according to the characteristics and essence of the learning experience, and holistic Assessment covering all aspects of learning objectives.

Authentic Assessment, according to O'Malley \& Pierce [13] includes performance assessment, portfolio, and self-assessment. Performance assessments are all types of assessments that require a response from the learner, where the reaction can be written or verbally based on the assignments given by the teacher. In responding, students are required to think critically to complete the tasks of open-ended questions. In the Assessment, both the process and the product are assessed. A portfolio is a collection of student assignments that show the progress of their learning, where the learner participates in determining which work is collected to show that progress. In this case, the study must indicate the instructional objectives and activities in the classroom. Self-assessment is an assessment made by the learners themselves, thus enabling them to do selfreflection. To facilitate this self-assessment, students are given examples of good assignments and then analyzed to be able to make assessment criteria. The scoring criteria created in the rating table are then used to rate their work.

Based on these three assessments, further O'Malley \& Pierce [13] divide the Assessment into several types, including interviews, storytelling, writing, projects/exhibitions, experiments/demonstrations, giving responses, teacher observations, and portfolio. This type of Assessment can show the learning process carried out by students, so it is used in assessments in the 2013 curriculum.

\section{METHOD}

A total of 117 participants took part in the survey and responded to the questions about their perceptions toward online learning in Japanese learning processes, assessments in education and the obstacles experienced by teachers during one year of learning. The data collection in the form of a questionnaire was carried out from October - December 2020. This study uses a descriptive quantitative approach. The quantitative part of the research is a questionnaire with two sections, and the qualitative part is an open-ended questionnaire.

Two sections for questions related to the learning process as many as 14 questions, while questions related to Assessment in learning as many as 7 questions. The open-ended questionnaire is a question related to the obstacles teachers face in learning Japanese online. In the quantitative part of the questionnaire, data analysis was carried out using a t-test, as well as analysis of variance (ANOVA).

\section{RESULTS AND DISCUSSION}

\subsection{Results}

The distribution of questionnaires to 117 high school/vocational Japanese teaching teachers in Bali provided data related to the teacher's perspectives and the obstacles they experienced. In terms of the teacher's perspective on the implementation/learning process, there are several results of the analysis. From Table 1, it can be seen that overall, teachers disagree with the question points related to the learning process during elearning. But there are several points where the teacher agrees with the statement that they provide explanations if students are not able to understand the concept well, or there are questions from students (3.41), then provide examples in order to help students find ideas (3.26), where the teacher gives students the opportunity observing videos, or other learning media (3.33), as well as facilitating students to learn independently by utilizing existing sources (books, internet, etc.) (3.31). During the learning process, the teacher gives clear instructions on tasks or projects that must be done by students (3.35) and always provides reinforcement (praise, emphasize mistakes, give marks as rewards, etc.) to students when they respond in learning online (3.29). Of the several points agreed by the teacher, there were also points that were not agreed upon, namely the statement that students who were less active during face-to-face learning became more active when learning online (1.99). 
Table 1. Description of Learning Implementation

\begin{tabular}{|c|c|c|c|}
\hline No & Statement Items & Mean & $\begin{array}{l}\text { Std. } \\
\text { Deviation }\end{array}$ \\
\hline 1 & $\begin{array}{l}\text { Formulation of activities in accordance with the } 2013 \text { curriculum that } \\
\text { emphasizes the poses scientifically }\end{array}$ & 2.9829 & .57209 \\
\hline 2 & Time allocation when online learning is the same as face-to-face learning. & 2.1197 & .86266 \\
\hline 3 & $\begin{array}{l}\text { I am able to bring up scientific learning that requires students to be active, } \\
\text { independent and think critically. }\end{array}$ & 2.6325 & .62420 \\
\hline 4 & $\begin{array}{l}\text { I give students the opportunity to observe videos or other learning media for } \\
\text { themselves. }\end{array}$ & 3.3333 & .60172 \\
\hline 5 & I facilitate students to find their own concepts from the material. & 2.9744 & .60830 \\
\hline 6 & I give examples in order to help students in finding concepts. & 3.2650 & .60733 \\
\hline 7 & $\begin{array}{l}\text { I give an explanation if students are not able to understand the concept well, or } \\
\text { there are questions from students. }\end{array}$ & 3.4188 & .63299 \\
\hline 8 & $\begin{array}{l}\text { I always explain the material first without asking students to find their own } \\
\text { concepts. }\end{array}$ & 2.4274 & .76919 \\
\hline 9 & I give clear instructions on assignments or projects to be done by students. & 3.3590 & .63601 \\
\hline 10 & $\begin{array}{l}\text { Students who are less active when learning face-to-face, become more active } \\
\text { when learning online. }\end{array}$ & 1.9915 & .64988 \\
\hline 11 & I can ask students to discuss in groups in online learning. & 2.4188 & .76833 \\
\hline 12 & I easily manage the class during online learning. & 2.3248 & .76371 \\
\hline 13 & $\begin{array}{l}\text { I always provide reinforcement (praise, emphasize mistakes, give marks as } \\
\text { rewards, etc.) to students when they respond in online learning. }\end{array}$ & 3.2991 & .60551 \\
\hline 14 & $\begin{array}{l}\text { I facilitate students to learn independently by utilizing existing resources (books, } \\
\text { internet, etc.) }\end{array}$ & 3.3162 & .59668 \\
\hline
\end{tabular}

Based on the results of the analysis of differences in the implementation of learning by gender (Table 2), no significant differences were found between male and female teachers (Sig. $>.05$ ). From the results of the analysis of differences in the implementation of learning based on education level (Table 2), no significant difference was found between teachers with bachelor and master levels (Sig. $>$.05.). Based on the results of the analysis of differences in the implementation of learning based on the length of teaching (Table 2), no significant differences were found. However, teachers with more than 20 years of teaching experience provide explanations if students are not able to understand the concept well or there are questions from students (Sig. .006).

In terms of the teacher's perspective on Assessment during online learning, there are several results of the analysis. From Table 3, it can be seen that overall, the teacher agrees with the question points related to the Assessment during e-learning. Teachers feel most agree with the statement that they use student responses during learning as the value of activity (3.29), where the Assessment of student activity during the learning process is carried out at any time (3.13). The teacher also agrees with the statement that the assignment as part of the Assessment has been recorded well (3.20), where the teacher provides feedback on the assignment or student's thinking (3.24). On the other hand, the teacher does not agree with the statement that in online learning, students can easily respond to assignments/projects made by their friends (2.58).

Based on the results of the analysis of differences in Assessment by sex (Table 4), no significant difference was found between male and female teachers (Sig. > .05). From the the results of the analysis of differences in Assessment based on education (Table 4), no significant difference was found between teachers with bachelor and master levels (Sig. $>.05$ ). Based on the results of the analysis of differences in Assessment based on length of teaching, several significant differences were found (Table 4). Teachers with 6-10 years of teaching experience plan assessments well before learning (Sig. 003), assignments as part of the Assessment have been recorded properly (Sig. .004), assessments of student activity during the learning process are carried out at any time (Sig. .004). Teachers with more than 20 years of 
teaching experience have a significant difference in the mean score on student responses during learning which is used as the value of activity (Sig. .022).

In general, the teachers experienced difficulty in monitoring students' understanding during the learning process. Students tend not to want to learn independently. More than $50 \%$ (63 people) of teachers stated that the signal/network was the main obstacle in the learning process, as well as the ability of students to purchase internet data packages. In addition, student readiness in which some students are not familiar/understand in using the platform used in the learning process. There are even students who do not have laptops/mobile phones that they can use in the learning process, so the teacher finds it difficult to contact them. Because of this, student attendance during the learning process cannot be maximized (besides there are students who are not present, many students are late in learning because of the poor network), in terms of working/collecting assignments, there is also a problem.

Table 2. Differences in Teacher's Perspective on Learning Implementation by Gender, Education and Teaching Length

\begin{tabular}{|c|c|c|c|c|c|c|}
\hline No & Gender & Sig & Education & Sig & Teaching Length & Sig \\
\hline 1 & F / M & .823 & Bachelor / Master & .469 & $<5 / 6-10 / 11-20 />20$ & .059 \\
\hline 2 & F / M & .193 & Bachelor / Master & .211 & $<5 / 6-10 / 11-20 />20$ & .417 \\
\hline 3 & F / M & .251 & Bachelor / Master & .583 & $<5 / 6-10 / 11-20 />20$ & .573 \\
\hline 4 & F / M & .213 & Bachelor / Master & .840 & $<5 / 6-10 / 11-20 />20$ & .430 \\
\hline 5 & F/M & .895 & Bachelor / Master & .634 & $<5 / 6-10 / 11-20 />20$ & .447 \\
\hline 6 & F/M & .332 & Bachelor / Master & .943 & $<5 / 6-10 / 11-20 />20$ & .104 \\
\hline 7 & F/M & .868 & Bachelor / Master & .840 & $<5 / 6-10 / 11-20 />20$ & .006 \\
\hline 8 & F/M & .701 & Bachelor / Master & .783 & $<5 / 6-10 / 11-20 />20$ & .393 \\
\hline 9 & F/M & .160 & Bachelor / Master & .222 & $<5 / 6-10 / 11-20 />20$ & .290 \\
\hline 10 & F/M & .445 & Bachelor / Master & .969 & $<5 / 6-10 / 11-20 />20$ & .110 \\
\hline 11 & F/M & .891 & Bachelor / Master & .758 & $<5 / 6-10 / 11-20 />20$ & .762 \\
\hline 12 & F/M & .581 & Bachelor / Master & .446 & $<5 / 6-10 / 11-20 />20$ & .418 \\
\hline 13 & F/M & .859 & Bachelor / Master & .333 & $<5 / 6-10 / 11-20 />20$ & .089 \\
\hline 14 & F/M & .474 & Bachelor / Master & .369 & $<5 / 6-10 / 11-20 />20$ & .204 \\
\hline
\end{tabular}

Table 3. Description of Assessment Analysis Results

\begin{tabular}{|c|l|c|c|}
\hline No & \multicolumn{1}{|c|}{ Statement Items } & Mean & $\begin{array}{c}\text { Std. } \\
\text { Deviation }\end{array}$ \\
\hline 1 & Assessment is well planned before learning. & 3.1880 & .54030 \\
\hline 2 & Assignments as part of the assessment have been recorded properly. & 3.2051 & .56536 \\
\hline 3 & Assessment of student activity during the learning process is carried out at any time. & 3.1368 & .62844 \\
\hline 4 & Student responses during learning are used as the value of activity. & 3.2991 & .66000 \\
\hline 5 & I give feedback on assignments or students' thinking. & 3.2479 & .64201 \\
\hline 6 & The questions given in the test during online learning are HOTS. & 2.8120 & .62879 \\
\hline 7 & $\begin{array}{l}\text { In online learning, students can easily respond to assignments/projects made by their } \\
\text { friends. }\end{array}$ & 2.5812 & .67261 \\
\hline
\end{tabular}

Various obstacles encountered during the learning process more or less caused students not to have the desire to follow the online learning process. It can be seen that students do not follow the learning process using various reasons. There is a tendency for students to be actively involved in the assessment process (collect assignments and take tests) but are not present when learning takes place. In specific platforms (which can be used by teachers and students), there are weaknesses that cause teachers to be unable to communicate directly with students, so teachers find it difficult, especially in facilitating students to practice speaking and discussing.

The Assessment carried out by almost all teachers (107 people) used daily assignments/tasks. The activeness of students in responding/answering to the 
teacher was used for Assessment by 69 teachers. The activeness that the teacher refers is different, there are teachers who use the responses/answers of students during learning, use responses/solutions, and absenteeism, there are even teachers who use the timeliness of collecting assignments and responses/answers during learning. An assessment is carried out through a test using a google form (midterm exam, final exam, quiz). Furthermore, the Assessment is carried out through a portfolio by 20 teachers and a project that makes videos (conversations, presentations) or making resumes by 24 teachers. There are also teachers who use attendance for Assessment.

Various obstacles caused the learning process not optimally, even in the Assessment that the teacher experienced. Teachers are not able to make assessments objectively and maximally according to students' abilities. Especially for new students, where the teacher did not know the basic skills of students. Some students are late in submitting assignments, even 1 to 2 weeks. Some even do not collect them at all. This causes doubts about students' independence in making assignments. So for teachers, projects and tests given online are not able to measure students' abilities correctly. This makes it difficult for teachers to determine students who really understand the material. In addition, online assignments and tests cause teachers cannot to provide feedback directly to the students. Downloading tasks takes a lot of time. Thus for teachers correcting student assignments and tests becomes a job that requires extra time and energy.

Most teachers give more written tests so that the Assessment of speaking skills cannot be facilitated. Teachers still find it challenging to choose an assessment model that is able to analyze the results quickly. In terms of student characteristics (in this case, attitude/personality assessment), the teacher has problems understanding each student because they only rely on the accuracy of collecting assignments and student attendance. The lack of student activity also makes attitude assessment difficult for teachers to do.

\subsection{Discussion}

The learning process can run well if in the learning process the conditions of all things related to learning are supported, both from students, teachers, and facilities (internet plans, networks, gadgets). If there are obstacles in the process, this will lead to problematic student motivation, so students become lazy to participate in online learning. Teacher knowledge, time management, and student motivation are obstacles felt by lecturers at universities in implementing e-learning [14]. The lack of teacher's experience in dealing with online learning causes the teacher to be not ready to carry out the teaching and Assessment, so the teacher cannot quickly solve the problems. This can be seen from the perspective of high school/vocational Japanese language teachers in Bali on the learning process, and Assessment carried out for approximately two semesters (in 2020).

The teacher's perspective regarding the learning process during the use of e-learning between male and female teachers, between teachers with bachelor and master levels, and between teachers who have different teaching durations, there is no significant difference. In the learning process, most teachers facilitate students to learn independently by giving students the opportunity to observe videos or other learning media for themselves. In this process, students are expected to take advantage of existing sources such as books, the internet, etc. The teacher only gives explanations when students are not able to understand the concept and when students ask questions. Examples are also provided to help students find ideas. During the learning process, the teacher gives clear instructions on the tasks or projects that must be done by students. What most teachers have done has shown that the student-centred approach as required in the 2013 curriculum has been applied. Even though the teacher has implemented learning with such an approach, according to the teacher, there is a tendency for students not to want to learn on their own and even not be active during the learning process. This, of course is influenced by certain factors.

More than $50 \%$ ( 63 people) of teachers stated that the network/signal was the main obstacle in the learning process and the financial ability of students in providing quotas. Poor network connectivity is indeed a significant obstacle in online learning [15],[16]. Due to signal/network and quota problems, student attendance during the learning process is not optimal (besides, there are students who are not present, many students are late for learning because of the poor network). Connection problems and internet data plans are also felt by Ghanaian students studying in China. They state that signal/network interference and high costs are obstacles in online learning [17]. Some students could not be present during the online class because they have to help their parents to support the family economy. Signal/network problems during the learning process cause students' responses tend to be slow. It affects the allocation of learning time that is not optimal.

During learning, students who can take part in the learning process are not actively participating. At this point, the teacher also encountered problems on how to motivate students to be active during the learning process. Although during the learning process, the teacher provides reinforcement (praise, emphasize mistakes, provide value as a reward, and so on) to students when they respond in online learning. But this is not able to make students become active in learning. This can be seen from the obstacles presented by the teacher regarding the lack of activeness of students during learning. Also reinforced by the results of the 
questionnaire, which showed the teacher's perspective on students who were less active when learning face-to-face, they did not become involved in online education. During the learning process, the teacher had difficulty in monitoring student understanding.

Student readiness is also one of the obstacles during the learning process, where some students are not familiar with/understand using the platform used in the learning process. According to [15], unawareness about online platforms is a major barrier in online learning apart from poor network connectivity and audio/video qualities. There are students who do not have laptops or gadgets that they can use in the learning process, causing teachers to have difficulty contacting students. This is undoubtedly very difficult for teachers in the learning process.

Various obstacles encountered during the learning process more or less caused students not to have the desire to follow the online learning process. It can be seen that students do not follow the learning process using various reasons. There is even a tendency for students to be actively involved in the assessment process (collect assignments and take tests) but are not present when learning takes place. There are weaknesses of the specific platform that cause teachers to be unable to communicate directly with students, especially in facilitating students to practice speaking and discussing. This certainly affects the Assessment made by the teacher, considering that the Assessment required in the 2013 curriculum is an assessment of the process, not only the result.

The teacher's perspective on the Assessment carried out during e-learning was applied between female and male teachers, and between teachers with bachelor and master levels did not have a significant difference. However, for teachers who have different years of teaching experience, some important differences were found. Teachers with 6-10 years of teaching experience have higher confidence in planning the Assessment well before learning. Assignments as part of the Assessment have been well recorded. Assessments of student activity during the learning process are carried out at any time. On the other hand, teachers with more than 20 years of teaching experience have higher confidence in using student responses during learning as an activity value.

In general, most of the teachers have done an excellent job recording, where the teacher provides feedback on the assignments or students' thoughts. But what the teacher regrets is that students cannot respond to assignments/projects made by their friends easily. The Assessment carried out by almost all teachers (107 people) used daily assignments/tasks. In addition, the activeness of students in responding/answering to the teacher was used for Assessment by 69 teachers. The activeness that is referred by the teacher here is different. There are teachers who look at the responses/answers of students during learning, from responses/answers and absenteeism, there are even teachers who see from the timeliness of collecting assignments and responses/answers during learning. An assessment is carried out through a test using a google form (midterm exam, final exam, quiz). Furthermore, the Assessment is carried out through a portfolio by 20 teachers and a project of making videos (conversations, presentations) or making resumes by 24 teachers. There are also teachers who use attendance for Assessment. Thus, only a few teachers have used the assessment model in accordance with the demands of the 2013 curriculum.

Most teachers give a written test so that the Assessment of speaking skills cannot be facilitated. Teachers still find it challenging to choose an assessment model that is able to analyze the results quickly. In terms of student characteristics (in this case, attitude/personality assessment), the teacher has problems understanding each student because they only rely on the accuracy of collecting assignments and student attendance. The lack of student activity also makes attitude assessment difficult for teachers to do. Thus, the Assessment required in the 2013 curriculum cannot be carried out optimally.

The obstacles in the Assessment are also caused by the network and quotas, where there are problems in the process of giving and receiving assignments. Teachers are not able to make proper and objective assessments. Online Assessment leaves teachers doubting the integrity of students in completing tasks. So, for teachers, assignments and tests given online are not able to measure students' abilities correctly. This makes it difficult for teachers to determine students who really understand the material. Assignments and tests are given online cause teachers correct direction on the monitor screen, which made providing feedback not be done directly. In addition, downloading tasks takes a lot of time. Thus, for teachers correcting student assignments and tests becomes a job that requires extra time and energy. Although there were teachers who conveyed various obstacles they experienced, six Japanese language teachers at High School/Vocational High School in Bali stated that there were no obstacles during the Assessment in e-learning.

\section{CONCLUSION}

There is no significant difference in the teacher's perspective regarding the learning process during the use of e-learning between male and female teachers, between teachers with bachelor and master levels, and between teachers who have different teaching durations. This is slightly different from the teacher's perspective on the Assessment carried out during e-learning. The teacher's perspective on the Assessment carried out during elearning is applied. The perspective between female and male teachers, as well as between teachers with bachelor and master levels did not have a significant difference. 
However, for teachers who have different years of teaching experience, some significant differences were found. There are various obstacles experienced by teachers in the learning and assessment process, which stem from the lack of facilities, lack of student readiness, and lack of teaching experience in planning assessments that are able to show students' abilities objectively.

\section{AUTHORS' CONTRIBUTIONS}

Desak Made Sri Mardan, conceived and designed the analysis, performed the analysis, wrote the paper.

I Wayan Sadyana collected the data, contributed data or analysis tools.

\section{ACKNOWLEDGMENTS}

This work is supported by DIPA BLU Undiksha grant, which makes this research possible.

\section{REFERENCES}

[1] The Japan Foundation, 日本語教授法シリーズ 9 : 初級を教えること.日本:ひつじ書房, 2007.

[2] M. K. P. Rahayu, "Barriers to use e-learning platform in indonesian higher education: Factors related to people and organization," Business and Management Research, vol. 100, p. 5.

[3] H. L. Steen, "Effective eLearning Design," vol. 4, no. 4, pp. 526-532, 2008.

[4] M. M. The and T. Usagawa, "A Comparative Study of Students' Readiness on E-learning Education between Indonesia and Myanmar," American Scientific Research Journal for Engineering, Technology, and Sciences (ASRJETS), vol. 40, no. 1, pp. 113-124, 2018.

[5] K. K. A. H. Singh and M. M. Yunus, "Using ELearning in English Language Teaching: A Systematic Review," IJARPED, vol. 10, no. 1, p. Pages 51-62, Feb. 2021, doi: 10.6007/IJARPED/v10-i1/8338.

[6] J. Ahmad, "English Language Teaching (ELT) and Integration of Media Technology," in ProcediaSocial and Behavioral Sciences, North Cyprus, 2012, vol. 47, pp. 924-929. doi: 10.1016/j.sbspro.2012.06.758.

[7] N. Oroujlou, "The importance of media in foreign language learning," in Procedia-Social and Behavioral Sciences, Antalya, Turkey, 2012, vol. 51. doi: 10.1016/j.sbspro.2012.08.113.

[8] Z. D. Yuldashevna and H. I. Tuhtayevich, "The use of ICT in foreign language learning and teaching," jcr, vol. 7, no. 05, Mar. 2020, doi: 10.31838/jcr.07.05.156.
[9] D. M. S. Mardani, I. W. Sadyana, and L. D. S Adnyani, "Learning Japanese Language Based on 2013 Curriculum at Elementary Schools in Bali," in Advances in Social Science, Education and Humanities Research, Sanur, Bali, 2020, vol. 394, pp. 246-251. doi: https://dx.doi.org/10.2991/assehr.k.200115.040.

[10] H. G. Tarigan, Dasar-Dasar Kurikulum Bahasa. Bandung: Angkasa, 2009.

[11] S. Arikunto, Dasar-Dasar Evaluasi Pendidikan. Jakarta: Bumi Aksara, 2009.

[12] M. S. Djiwandono, Tes Bahasa, Pegangan bagi Pengajar Bahasa. Jakarta: Indeks, 2008.

[13] N. N. Padmadewi and P. D. Merlyna, Asesmen Kurikulum 2013. Singaraja, Bali, 2015.

[14] S. Windiarti, N. Fadilah, E. Dhermawati, and B. W. Pratolo, "Teachers' Perception toward the Obstacles of E-Learning Classes," Ethical Lingua, vol. 6, no. 2, pp. 117-128, Sep. 2019, doi: 10.30605/25409190.v6.117-128.

[15] S. S. Alavudeen et al., "The influence of COVID19 related psychological and demographic variables on the effectiveness of e-learning among health care students in the southern region of Saudi Arabia," Saudi Pharmaceutical Journal, vol. 29, no. 7, pp. 775-780, Jul. 2021, doi: 10.1016/j.jsps.2021.05.009.

[16] T. Muthuprasad, S. Aiswarya, K. S. Aditya, and G. K. Jha, "Students' perception and preference for online education in India during COVID -19 pandemic," Social Sciences \& Humanities Open, vol. 3, no. 1, p. 100101, 2021, doi: 10.1016/j.ssaho.2020.100101.

[17] J. Demuyakor, "Coronavirus (COVID-19) and Online Learning in Higher Institutions of Education: A Survey of the Perceptions of Ghanaian International Students in China," ONLINE J COMMUN MEDI, vol. 10, no. 3, p. e202018, May 2020, doi: 10.29333/ojcmt/8286. 